高緯度における位置の線（II）

\title{
Position Lines at High Latitudes (II)
}

進士 晃 (水路部)

\begin{abstract}
In the last paper, we treated the errors of line of position that is plotted on the Mercator's chart and found that the error due to the convergency of meridian was most severe for the high latitudes. At this paper, in order to exclude this error, we get the stereographic projection from the conditions of conformality for polar representation.

We investigate the characters of the errors of line of position on this projection arising from: (i) the length of intercept taken from the latitude graduation, (ii) the position of the terminal of intercept plotted as straight line, (iii) the azimuth of position line plotted perpendicular at the terminal of straight line intercept, and (iv) the line of position as approximation of the circle of position.

The resultant effect to the fixed position is sufficiently small for the ordinary air or surface navigation at higher latitudes, for example, less than one mile for latitude $80^{\circ}$, and less than four miles even for latitude $60^{\circ}$.

For the polar navigation, we adopt the pole itself as an assumed position and can easily plot the line of position without computation. A simple correction table for the curvature of position line is provided, which can be used for the whole polar region higher than latitude $85^{\circ}$.
\end{abstract}

\section{$\S 1 \cdot$ は じめに}

㳥長海困に位置の線を記入して求めを船位には、高緯度では種及の誼差の影響が表われてく る。前回（航海学会誌、第15号25ページ）には、との誤差の性質について調べ、緯度が $70^{\circ}$ 程度 まででは、まずの影響は無視できるととを見た。こんどはさらと緯度が高くなつを場合の四法 につんて考えるととにする。

漸長図に記入しを位置の線の、高緯度に壳ける最も致命的な欠陷は、子午線の集合差による方 位の誤差であつた。それでんまの場合飞用5る図法が備5べき条件として：（i ）子午線の集合 差が表われ就しと、(ii) 等角写像であるととの2つを採る。

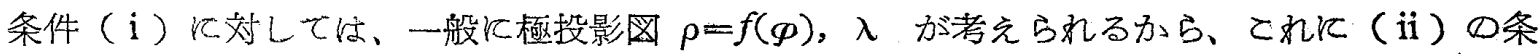
件

$$
\frac{\partial x}{\partial \varphi} \frac{\partial x}{\partial \lambda}+\frac{\partial y}{\partial \varphi} \frac{\partial y}{\partial \lambda}=0,\left(\frac{\partial x}{\partial \lambda}\right)^{2}+\left(\frac{\partial y}{\partial \lambda}\right)^{2}=\cos ^{2} \varphi\left\{\left(\frac{\partial x}{\partial \varphi}\right)^{2}+\left(\frac{\partial y}{\partial \varphi}\right)^{2}\right\}
$$


を入れると

$$
\{f(\varphi)\}^{2}=\cos ^{2} \varphi \cdot\left(\frac{\partial f}{\partial \varphi}\right)^{2}
$$

を得て、この解は、 $h$ を常数として

$$
f(\boldsymbol{\rho})=h \tan \left(\frac{\pi}{4} \pm \frac{\varphi}{2}\right)
$$

とをる。とれは平射図法 stereographic projection の表示で、との場合に地球は函数諭でんう Riemann の球核当し、極机んて平面に接してんる。

乙の球面上の 1 点 $(\xi, \eta, \zeta)$ 亡、その搑影 $(x, y)$ との変換式は、球の半径を $a$ として

$$
\xi=\frac{4 a^{2} x}{x^{2}+y^{2}+4 a^{2}}, \eta=\frac{4 a^{2} y}{x^{2}+y^{2}+4 a^{2}}, \zeta=\frac{2 a\left(x^{2}+y^{2}\right)}{x^{2}+y^{2}+4 a^{2}}
$$

である。この点の球面上の経緯度を $\lambda, \varphi$ とし、 $\lambda$ は $\xi-\zeta$ 平面から $\eta$ 軸の正方向に測り、 $\phi$ は 赤道から原点である極炿つて正にとるるのとする。との点を中心、 $\theta$ を半径とする小円を考え るとその方程式は

$$
\cos \varphi \cdot \cos \lambda \cdot \xi+\cos \varphi \cdot \sin \lambda \cdot \eta-\sin \varphi \cdot \zeta=a(\cos \theta-\sin \varphi)
$$

であつて、てれに（2）の変換を施すと

を得る。とれは

$$
x^{2}+y^{2}-\frac{4 a \cos \varphi \cos \lambda}{\cos \theta+\sin \varphi} x-\frac{4 a \cos \varphi \sin \lambda}{\cos \theta+\sin \varphi} y+4 a^{2} \frac{\cos \theta-\sin \varphi}{\cos \theta+\sin \phi}=0
$$

中心: $\frac{2 a \cos \varphi \cos \lambda}{\cos \theta+\sin \varphi}, \frac{2 a \cos \varphi \sin \lambda}{\cos \theta+\sin \varphi}$

半径: $\rho=\frac{2 a \sin \theta}{\cos \theta+\sin \varphi}$

の円である。

んま（3）の平面が原点と反対側の極を通るとをには、原点からとの平面までの距離が

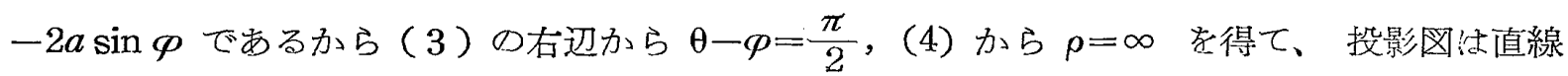
である。

まを（3）の平面が原点である極を通るとをには、その右辺は 0 そ等しく、 $\theta+\varphi=\frac{\pi}{2}$ となり (4) から

となる。

$$
\rho=a \tan \theta=a \cot \varphi
$$

以上が平射図法に和ける位置の円の性質である。ここに $\phi, \lambda$ は天体 $(\alpha, \delta)$ の地上位置で あつて $\lambda=h_{G}=\Theta_{G}-\alpha, \varphi=\delta$, また $\theta$ は天頂距離である。

以下、地球の半径 $a$ を単位にとり、平射図法の通常の表現飞し觉がつて（1）を

$$
\rho=2 \tan \left(\frac{\pi}{4}-\frac{\varphi}{2}\right)
$$

の形で使らととにする。との式に対しては

$$
\rho=2 \tan \left(\frac{\pi}{4}-\frac{\varphi}{2}\right)=2(\sec \varphi-\tan \varphi)
$$

の関係があり、委た $\psi=\frac{\pi}{2}-\varphi$ とおけば $\psi<1 \quad$ に対して 


$$
\rho=2 \tan \frac{\psi}{2}=\sin \psi+\sin \psi \sin ^{2} \frac{\psi}{2}+\sin \psi \sin ^{4} \frac{\psi}{2}+\cdots \cdots \cdots
$$

の展開ができて、 $\varphi=60^{\circ}$ すなわち $\psi=30^{\circ}$ に対しては第 2 項は 0.034 であるから

$$
\rho=2 \tan \frac{\psi}{2} \fallingdotseq \cos \varphi
$$

の近似を、 $\rho$ の高次に対しては適用でをる。

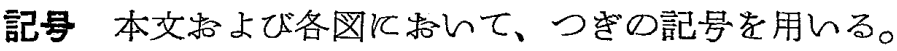

$\lambda, \varphi:$ 経緯度

$I, Z$ : 修正差

$A:$ 推定（まを仮定）位置

$F:$ 修正差の端点

$P$ : 地球の極、投影面亡接しない

$Q ：$ "、投影面と接する

\section{§2. 修正差の長さ}

推定（または仮定、以下抾なじ）位置 $A$ か ら修正差 $A F^{\prime}$ 直線で引き、その方位を $Z$ 、 紙面上の実長を $S$ とする。(第1図)

一般飞等角投影図の縮尺は

$$
H=\frac{1}{a}\left\{\left(\frac{\partial x}{\partial \varphi}\right)^{2}+\left(\frac{\partial y}{\partial \varphi}\right)^{2}\right\}^{\frac{1}{2}}
$$

で与えられるから、平射図法では

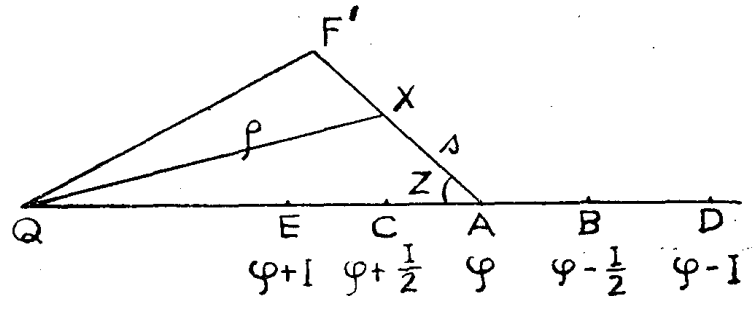

Fig. 1

$$
H=\sec ^{2}\left(\frac{\pi}{4}-\frac{\varphi}{2}\right)=1+\left(\frac{\rho}{2}\right)^{2}
$$

となる。 $A F^{\prime}$ 上の任意の 1 点を $X$ とし、 $\overline{A X}=s, \overline{Q A}=\rho_{A}, \overline{Q X}=\rho$ とすれば、Sの地球面上飞和 ける実距離は

$$
\begin{aligned}
I^{\prime} & =\int_{A}^{F^{\prime}} \frac{d s}{H}=\int_{0}^{S}\left(1+\frac{\rho_{A}{ }^{2}}{4}-\frac{\rho_{A}}{2} \cos Z \cdot s+\frac{s^{2}}{4}\right)^{-1} d s \\
& =2\left(1+\frac{\rho_{A}{ }^{2}}{4} \sin ^{2} Z\right)^{-\frac{1}{2}}\left[\tan ^{-1} \frac{1}{2}\left(s-\rho_{A} \cos Z\right) \cdot\left(1+\frac{\rho_{A}{ }^{2}}{4} \sin ^{2} Z\right)^{-\frac{1}{2}}\right]_{0}^{S}
\end{aligned}
$$

との積分の主要項を採つて

$$
I^{\prime}=S-S\left(\frac{\rho_{A}}{2}\right)^{2}+\frac{S^{2}}{2} \cdot \frac{\rho_{A}}{2} \cos Z
$$

を得る。

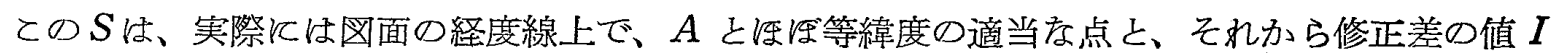
だけ缡つを点とに、それぞれ両脚器の両端を当てて採つたすのとする。縮尺が欄外に示されてん るとき、これ準する。ん経度線 $Q A$ 上飞点 $B, C, D, E$ を採 $b, A$ の緯度を $\varphi$, 以下 それぞれの緯度を $\varphi-\frac{I}{2}, \phi+\frac{I}{2}, \phi-I, \phi+I$ とする。(6) から

$$
\Delta \rho=-\Delta \varphi-\Delta \varphi \tan ^{2} \frac{\psi}{2}+\frac{\Delta \phi^{2}}{2} \tan \frac{\psi}{2}
$$

となるから 


$$
\begin{aligned}
& S_{D A}=I+I \tan ^{2} \frac{\psi}{2}+\frac{I^{2}}{2} \tan \frac{\psi}{2} \\
& S_{A D}=I+I \tan ^{2} \frac{\psi}{2}-\frac{I^{2}}{2} \tan \frac{\psi}{2} \\
& S_{B O}=I+I \tan ^{2} \frac{\psi}{2}
\end{aligned}
$$

これらを順に（9）飞代入すれば

$$
\begin{aligned}
& I_{D A}^{\prime}=I+\frac{I^{2}}{2} \tan \frac{\psi}{2}(1+\cos Z) \\
& I_{A B}^{\prime}=I-\frac{I^{2}}{2} \tan \frac{\psi}{2}(1-\cos Z) \\
& I_{B C}^{\prime}=I+\frac{I^{2}}{2} \tan \frac{\psi}{2} \cos Z
\end{aligned}
$$

しそがつて修正差を経度線上の緯度目盛から採つをととれよる誤差は、（8）を使つて

$$
\Delta I=\left\{\begin{array}{l} 
\pm \frac{I^{2}}{4} \cos \varphi(1 \pm \cos Z) \\
\frac{I^{2}}{4} \cos \varphi \cos Z
\end{array}\right.
$$

となる。あるいは $I ， \Delta I$ をマイルで表わすならば

$$
\Delta I=\left\{\begin{array}{c} 
\pm 0.7 \times 10^{-4} I^{2} \cos \varphi(1 \pm \cos Z) \\
0.7 \times 10^{-4} I^{2} \cos \varphi \cos Z
\end{array}\right.
$$

\section{§3. 修正差端点の位置}

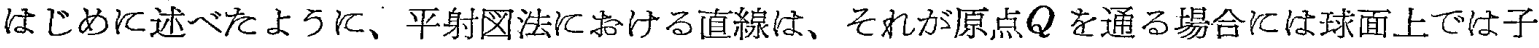
午線であり、原点を通らない場合には極 $P$ を通る小円である。それで推定位置 $A(\varphi, \lambda)$ から修 正差 $A F(I, Z)$ を直線で引んをとを、その地球面上に拉ける位置は、 $A F P$ を通る平面之地球 面之が交わつて生する小円である。

この小円上で緯度が最大となる点を $R$ とすれば、(第2、第 3 図)その図面上べの投影 $R$ は $Q$ から $A F$ へ下した重線の足であつて

$$
\angle A Q R=90^{\circ}-Z, \quad Q R=\rho_{A} \sin Z=2 \tan \frac{\psi_{R}}{2}
$$

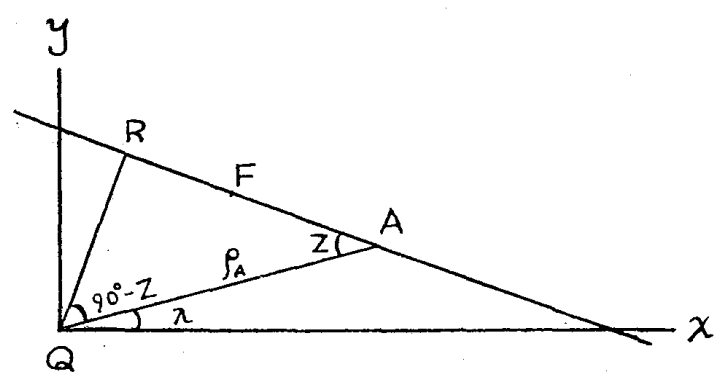

Fig .2

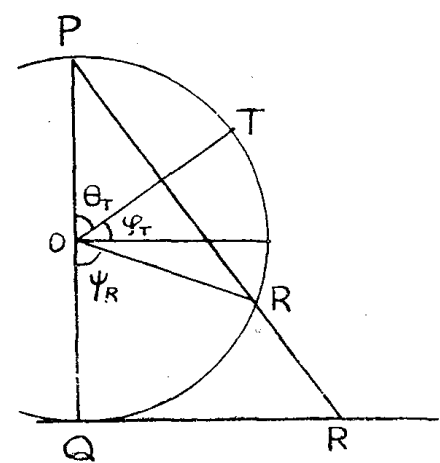

Fig. 3

また $Q A=\rho_{A}=2 \tan \frac{\psi_{A}}{2}$ であるから 


$$
\psi_{R}=2 \tan ^{-1}\left(\rho_{A} \sin Z / 2\right)
$$

亡なる。小円 $P R$ の中心を $T$ 、半径を $\theta_{T}$ とすれば

$$
\theta_{T}=\frac{1}{2}\left(180^{\circ}-\psi_{R}\right)=90^{\circ}-\tan ^{-1}\left(\rho_{A} \sin Z / 2\right)
$$

したがつて $T$ の緯度は

$$
\varphi_{T^{\prime}}=-\left(90^{\circ}-\theta_{T^{\prime}}\right)=-\tan ^{-1}\left(\rho_{A} \sin Z / 2\right)
$$

である。すなわち修正差 $A F$ は地球上では $T\left(-\tan ^{-1}\left(\rho_{A} \sin Z / 2\right), 90^{\circ}-Z+\lambda\right)$ を中心、 $90^{\circ}-\tan ^{-1}\left(\rho_{A} \sin Z / 2\right)$ を半徍とする小円の弧である。とれから、との小円の方程式として

$$
-\sin \left(\Lambda-\lambda_{A}+Z\right)=\frac{\rho_{A}}{2} \sin Z(\sec \Phi+\tan \Phi)
$$

を得る。 $\Lambda, \Phi$ は経緯度の流通座標である。

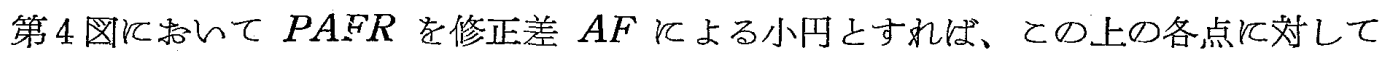
$-\sin \Phi=\cos ^{2} \theta_{T}+\sin ^{2} \theta_{T} \cdot \cos \mu$

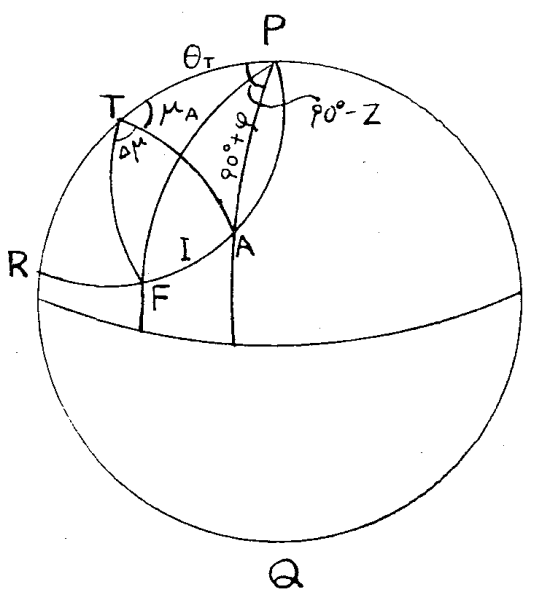

Fig. 4

ことに $\mu$ は $P$ と小円上の1点とに対して $T$ にいて張 る角である。

々ま $\phi_{F}=\varphi+\Delta \phi^{\prime}, \quad \lambda_{F}=\lambda+\Delta \lambda^{\prime}$ とすれば、上の式か ら

$$
\Delta \varphi^{\prime}=\frac{\sin ^{2} \theta_{T}}{\cos \phi}\left(\Delta \mu \sin \mu+\frac{\Delta \mu^{2}}{2} \cos \mu\right)+\frac{\Delta \mu^{2}}{2} \tan \phi
$$

しかるK

$$
\Delta \eta=\angle A T F=I / \sin \theta_{T}
$$

であり、また $\angle T P A=\angle R Q A$ (第 2 図) $=90^{\circ}-Z$ 亡な つて、球面 3 角形 $P T A$ 力ら $\sin \mu_{A} / \cos \varphi=\cos Z / \sin \theta_{T}$ $\sin \theta_{T} \cos \mu_{A}=-\sin \varphi \sin \theta_{T}-\cos \varphi \cos \theta_{T} \sin Z$

を得、をを(13)，（7）から

$\cot \theta_{T}=\rho_{A} \sin Z / 2=(\sec \phi-\tan \varphi) \sin Z$

こなるから、これらの関係を使えば（16）は

$$
\Delta \varphi^{\prime}=I \cos Z-\frac{I^{2}}{2} \sec \varphi \sin ^{2} Z
$$

さらに (15) から

$$
\Delta \lambda^{\prime}=\Delta \varphi \sec \varphi \tan Z+\frac{\Delta \varphi^{2}}{2}(\tan \varphi+\sec \varphi) \sec \varphi \tan Z
$$

となり、(18)を入れて

$$
\Delta \lambda^{\prime} \cdot \cos \varphi=I \sin Z+\frac{I^{2}}{2}(\tan \varphi+\sec \varphi) \sin Z \cos Z
$$

を得る。ててに（18），(19）の展開は 2 次に止めてあるが、3次以降の項は順次、近似的に

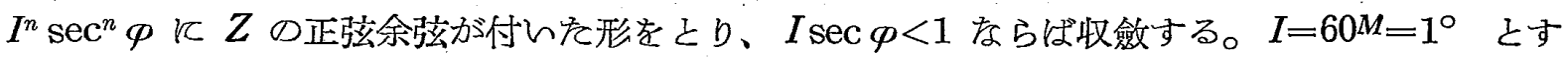
れば $\phi<89^{\circ} ， I=120^{M=}=2^{\circ}$ とすれば $\phi<88^{\circ}$ で収斂することになり、 $\varphi=85^{\circ}$ では $I=1,2^{M}$ に対してそれぞれ $I \sec \varphi$ は $0.2 ， 0.4$ となり 3 乗の項以降は十分に省略できる。

修正差は本来、推定位置から天体の地上位置へ引いた大円の一部でなければならない。とのよ 5にして採つを修正差を $A F_{1}$ とし、 $\phi_{F_{1}}=\varphi+\Delta \varphi_{1}, \lambda_{F_{1}}=\lambda+\Delta \lambda_{1}$ とすれば、球面 3 角形 $P F_{1} A$ 
から

$$
\Delta \varphi_{1}=I \cos Z-\frac{I^{2}}{2} \tan \varphi \sin ^{2} Z
$$

$\Delta \lambda_{1} \cos \varphi=I \sin Z+I^{2} \tan \varphi \sin Z \cos Z$

となる。結局、修正差を直線で引んたととれよる誤差は

$$
\begin{aligned}
& \Delta \varphi=\Delta \phi^{\prime}-\Delta \varphi_{1}=-\frac{I^{2}}{4} \cos \varphi \sin ^{2} Z \\
& \Delta \lambda \cdot \cos \varphi=\Delta \lambda^{\prime} \cos \varphi-\Delta \lambda_{1} \cos \varphi=\frac{I^{2}}{4} \cos \varphi \sin Z \cos Z
\end{aligned}
$$

あるいは単位をマイルで表わして

$$
\begin{aligned}
& \Delta \phi=-0.7 \times 10^{-4} I^{2} \cos \varphi \sin Z \\
& \Delta \lambda \cdot \cos \varphi=0.7 \times 10^{-4} I^{2} \cos \varphi \sin Z \cos Z
\end{aligned}
$$

となる。

\section{§4. 位置の線の方位}

直線で引んた修正差の端点 $F$ 亿和ける修正差の方位 $Z^{\prime}$ は、推定位置 $A$ に和ける方位に $A, F$ 2 点の経度差を加えたるのに等しん。すをわち

$$
\Delta Z^{\prime}=Z^{\prime}-Z=\Delta \lambda
$$

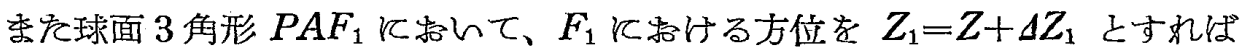

$$
\Delta Z_{1}=I \tan \varphi \sin Z+\frac{I^{2}}{2}\left(\sec ^{2} \varphi+\tan ^{2} \varphi\right) \sin Z \cos Z
$$

を得る。

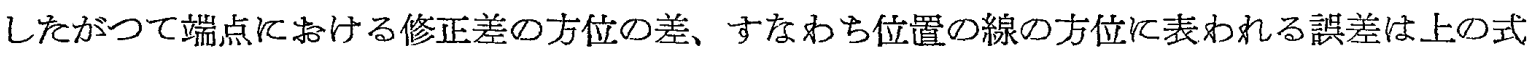
之(19) から

$$
\Delta Z=\Delta Z^{\prime}-\Delta Z_{1}=\frac{I}{2} \cos \varphi \sin Z
$$

あるいは、 $I$ をマイル、 $\Delta Z$ を度で表わすならば

$$
\Delta Z=0.83 \times 10^{-2} I \cos \varphi \sin Z
$$

\section{§5. 位置の円と位置の線との差}

位置の線は地球上では極を通る小円であるから、位置の円と位置の線との差は、地球面上では 修正差端点とおんて接する 2 月閒の距離のととである。との距離が最も大きくなるのは、位置の 線による円弧が大円の場合である。地球上の 1 点に和んて接する大円と小円と距離につんては多 く教科書に触れてあるが、ん鈴木敬信 “地文及天文航法” (昭和 22 年) 185 ページに従えば

$$
X=\frac{D^{2}}{2} \tan a+\frac{D^{4}}{8} \tan ^{3} a
$$

である。ててと $D$ は接点から大円上の 1 点をでの距離、 $X$ はとの点から重直に測つを小円をで の距離であり、 $a$ は小円の半径の余角すをわち天体の高度である。 $X, D$ をマイル単位で表わせ ば

$$
X=1.45 \times 10^{-4} D^{2} \tan a
$$

である。とれにょつて計算しを值は §7 亿表として示してあり、通常言われているよらに、高度 が $60^{\circ}$ 以下であれば無視できる。 


\section{§6. 船位への影響}

以上の過程によつて生ずる位置の線の誤差が、船位の決定にでのよう飞影響するかを検討す る。亦修正差の長されは（10）まをは（11）の性質の誤差が入り、さらにての愦差を補つても その端点は（20)，(21）だけずれる。それで

$$
\sigma^{2}=\Delta \phi^{2}+\Delta \lambda^{2} \cdot \cos ^{2} \varphi
$$

とすれば、(20)，(21）から

$$
\sigma=\frac{I^{2}}{4} \cos \varphi \sin Z
$$

あるんは $I, \sigma$ をマイルで表わせば

$$
\sigma=0.7 \times 10^{-4} \cos \varphi \sin Z
$$

端点の位置のず㞦にる修正差の長さの愦差を $\Delta J$ とすれば $\Delta J \leqq \sigma$ である。（10）または（11） と（24）との合成しを結果は、方位 $Z$ の係数を最大にとれば

$$
d I=\frac{3}{4} I^{2} \cos \varphi
$$

であつて、てれが修正差の長され生ずる最大の䛊差である。

方位の誤差は（22）で与えられる。

船位を直角座標 $x, y$ で表わしを場合に、修正差の長され括ける誤差 $d I$ と、方位沈和ける誤差 $d Z$ 亡による船位の誤差は前回に述べをように

$$
\begin{gathered}
d x=\left(d I_{1} \sin Z_{2}-d I_{2} \sin Z_{1}+D_{1} \sin Z_{2} d Z_{1}-D_{2} \sin Z_{1} d Z_{2}\right) \csc \left(Z_{1}-Z_{2}\right) \\
d y=\left(-d I_{1} \cos Z_{2}+d I_{2} \cos Z_{1}-D_{1} \cos Z_{2} d Z_{1}+D_{2} \cos Z_{1} d Z_{2}\right) \csc \left(Z_{1}-Z_{2}\right)
\end{gathered}
$$

であるから、との式中の $d I, d Z$ へそれぞれ (25), (22) を入れると、求める船位の愦差 $\dot{d}=\sqrt{(d x)^{2}+(d y)^{2}}$ が得られる。ん柰、かりに2 条の位置の線が同じ $d I, d Z$ を持つていると して、修正差の端点から位置の線の交点委での距離 $D=30,60,120 \mathrm{M}$ 亿㐫する $d s$ の值を求め

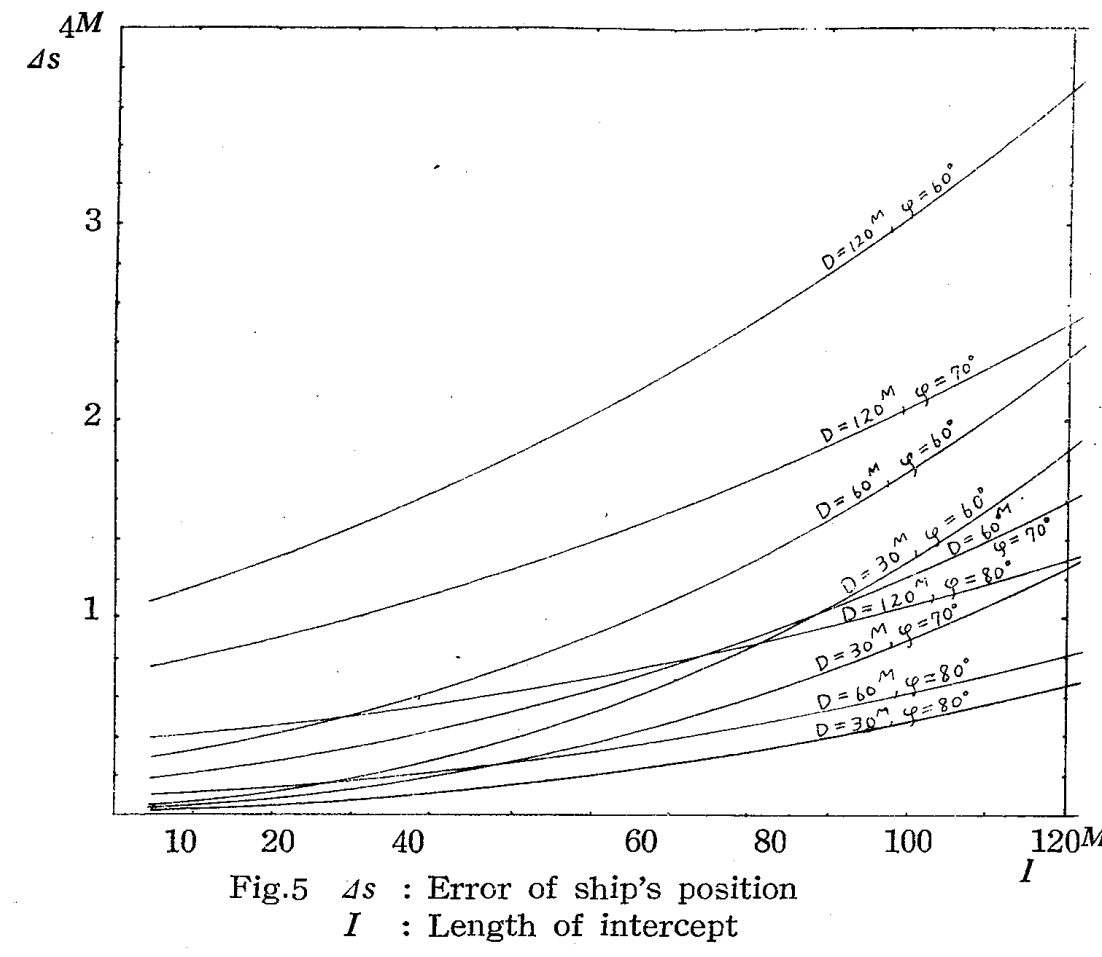
ると第5㘡のようになる。 緯度 $80^{\circ}$ 以上では船位に与 える䛩差は $1^{M}$ 以下であり 委を低く緯度 $60^{\circ}$ に和んて さえ $4^{M}$ 超えない。この 精度は航空機の場合だけで なく、船船炕対する天測愦 差としても許容できよう。 （本号23ページ、塚本氏の 論文参照)

つぎに漸長図における誤 差と比較してみる。ん亦れ の四法を用いるにしても、 上の $d x, d y の$ 式で, $d I$ そ $d Z$ 以外は共通であるから、両 図法衹ける船位の誤差は $d I+D d Z$ 次此例すると考 
えるととができる。

漸長図の場合汇は

$$
d I=-\frac{I^{2}}{2} \tan \varphi \cdot(1-\cos Z), \Delta Z=I \tan \varphi \sin Z
$$

であつたから、 $Z$ の項につんて最大值を採つて

$$
\sum M=d I+D d Z=\left(I^{2}+D I\right) \tan \varphi
$$

平射図法の場合には、同様に $Z$ 亿つんては最大値を採つて (25)，(22) から

$$
\Sigma s=\left(\frac{3}{2} I^{2}+D I\right)(\sec \phi-\tan \phi)
$$

ててにのの項は (25)，(22）に和ける近似を本来の形に屎したものである。便宣上、DIの項を 過大採つて

$$
\Sigma s^{\prime}=\frac{3}{2}\left(I^{2}+D I\right)(\sec \phi-\tan \phi)
$$

とすると

$$
\frac{\sum s^{\prime}}{\sum M}=\frac{3}{2} \frac{\sec \varphi-\tan \varphi}{\tan \varphi}=\frac{3}{2}(\csc \varphi-1)
$$

となる。との值をつぎに示す。

$$
\begin{array}{clllllll}
\boldsymbol{\varphi} & 37^{\circ} & .45^{\circ} & 60^{\circ} & 70^{\circ} & 75^{\circ} & 80^{\circ} & 85^{\circ} \\
\Sigma S^{\prime} / \Sigma M & 0.99 & 0.62 & 0.23 & 0.10 & 0.05 & 0.02 & 0.01
\end{array}
$$

すなわち、 $\varphi=37^{\circ}$ で両図法がそれぞれ船位に与える愦差は在疼等しく、それから緯度が高くな るとしをがつて、平射図法の方が精度は急激に高くなる。しかも $D I$ を過大に採つをととを考え ると、この此はさらに大をくなる。

\section{§7. 極 地 航 法}

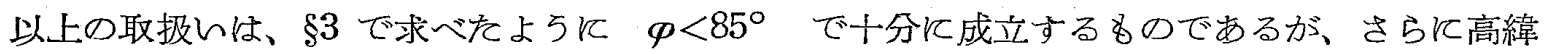
度では、極そのるのを仮定位置炕採用するととが考えられる。

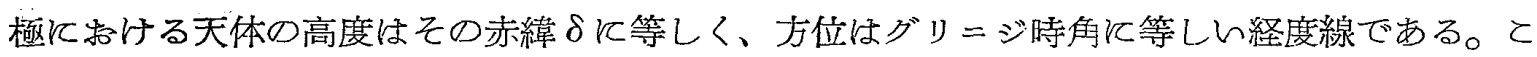
れらは天測暦、略暦から直接に得られるものであるから、天測計算は全く必要としない。すねわ

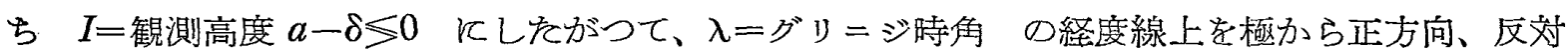
方向にIだけ採り、その端点に立てた重線が位置の線である。

てのようにして位置の線を描くならば、投影図法の誤差は修正差には入らす、位置の円と位置 線の美だけが誤差の原因となる。

位置の円が原点を通る場合には、その半径は（5）飞よつて与えられ、との円之極流んて接 する直線すなわち経度線（位置の線と考える）との距離は（23）で与えられる。つぎそその值を 示す。 
大円と小円之の間隔（单位：マイル)

両円の接点から大円上に距離 $D$ の点をとり，その点から垂直に測つた小円(半 径 $\left.90^{\circ}-a\right)$ までの距離 $\mathrm{X}$

\begin{tabular}{|c|c|c|c|c|c|c|c|c|c|c|}
\hline$a$ & 0.25 & 0.50 & 0.75 & 1.00 & 1.25 & 1.50 & 1.75 & 2.00 & $2^{\circ} .25$ & 2.50 \\
\hline $85^{\circ}$ & 0.4 & 1.5 & 3.4 & 6.1 & 9.5 & 13.8 & 18.9 & 25.0 & 32.0 & 40.1 \\
\hline 80 & 0.2 & $0.8^{-}$ & 1.7 & 3.0 & 4.7 & 6.7 & 9.2 & 12.0 & 15.2 & 18.9 \\
\hline 70 & 0.1 & 0.3 & 0.8 & 1.4 & 2.2 & 3.2 & 4.4 & 5.8 & 7.3 & 9.0 \\
\hline 60 & 0.1 & 0.2 & 0.5 & 0.9 & 1.4 & 2.0 & 2.81 & 3.6 & 4.6 & 5.7 \\
\hline 50 & 0.0 & 0.2 & 0.3 & 0.6 & 1.0 & 1.4 & $1.9^{2}$ & 2.5 & 3.2 & 3.9 \\
\hline 40 & 0.0 & 0.1 & 0.2 & 0.4 & 0.7 & 1. 0 & 1.3 & $1.7^{-\infty}$ & $\overline{2.2}$ & 2.7 \\
\hline 30 & 0.0 & 0.1 & 0.2 & 0.3 & 0.5 & 0. & 0. & 1.2 & $1 . \overline{5}$ & 1.9 \\
\hline 20 & 0.0 & 0.1 & $0 . \overline{1}$ & 0.2 & 0.3 & 0.4 & 0.6 & $0 . \overline{8}$ & 1.0 & 1.2 \\
\hline 10 & 0.0 & 0.0 & 0.0 & 0.1 & 0.1 & 0.2 & 0.3 & 0.4 & 0.4 & 0.6 \\
\hline \multirow[t]{2}{*}{5} & 0.0 & 0.0 & 0.0 & 0.1 & 0.1 & 0.1 & 0.1 & 0.2 & 0.2 & 0.3 \\
\hline & 2.75 & 3.00 & 3.25 & 3.50 & 3.75 & 4.00 & 4.25 & 4.50 & 4.75 & 5.00 \\
\hline & & & & & & & & & & \\
\hline $85^{\circ}$ & 49.3 & 59.8 & 71.8 & 85.5 & 101.2 & 119.5 & 141.3 & 168.2 & 206.1 & 279.3 \\
\hline 80 & 22.9 & 27.4 & 32.2 & 37.5 & 43.3 & 49.5 & 56.2 & 63.5 & 71.2 & 79.4 \\
\hline 70 & 10.9 & 13.0 & 15.3 & 17.7 & 20.4 & 23.2 & 26.3 & 29.5 & 32.9 & 36.5 \\
\hline 60 & 6.9 & 8.2 & 9.6 & 11.1 & 12.8 & 14.6 & 16.4 & 78.5 & 20.6 & 22.8 \\
\hline 50 & 4.7 & 5.6 & 6.6 & 7.7 & 8.8 & 10.0 & 11.3 & $12.7^{\circ}$ & 14.1 & 15.6 \\
\hline 40 & 3.3 & 4.0 & 4.6 & 5.4 & 6.2 & 7.0 & 7.9 & 8.9 & 9.9 & 11.0 \\
\hline 30 & 2.3 & 2.7 & 3.2 & 3.7 & 4.3 & 4.8 & 5.5 & 6.1 & 6.8 & 7.6 \\
\hline 20 & 1.4 & 1.7 & 2.0 & $\overline{2.3}$ & 2.7 & 3.1 & 3.4 & 3.9 & 4.3 & 4.8 \\
\hline 10 & 0.7 & 0.8 & I. 0 & I. $I$ & $1.3^{2}$ & 1. & 1.7 & 1.9 & 2.1 & $\overline{2.3}$ \\
\hline 5 & 0.3 & 0.4 & 0.5 & 0.6 & 0.7 & 0.8 & 0.8 & 0.9 & 1.0 & 1.1 \\
\hline
\end{tabular}

塚本氏の所論飞従つて天文航泆の精度を一般船舶に対して $3^{\prime}$ 、航空機に対して $20^{\prime}$ とし、それ らの限界を表中にそれぞれ太線で示してある。すねわち高度 $60^{\circ}$ 以下てつんて船船の場合飞は、 修正差端点から船位までの距離 $D$ が $120 M$ 以内の範囲で、委を航空機の場合には D が300M 以内の範囲で位置の円を直線で表わし得る。との限界を越える場合には、推定される位置の近傍 そ和んて、D, $a$ 亿応じて表によつて $X$ だけ補正をすれば位置の円となる。極では大陽・月・ 惑星の高度は $30^{\circ}$ 以下である。表中、太字で示してあるのは、とめ境界学指す。

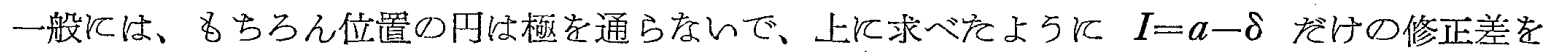

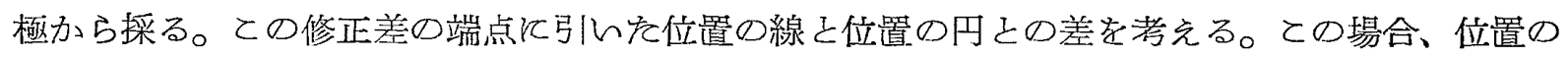
線は地球面上では $90^{\circ}-\frac{I}{2}$ を半径とする小円であるから、とれとIの端点に制んて接する大円

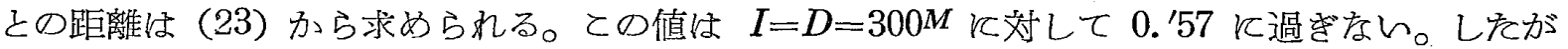
つて、との精剫以内ならば、 $I<5^{\circ} ， D<5^{\circ}$ 亿対して、位置の線は地球面上では大円と見なすて とがでをるから、位置の線の位置の円に対する補正も極に対する上表を分単位に 4 捨 5 入するこ とによつて、その季委適用でをる。

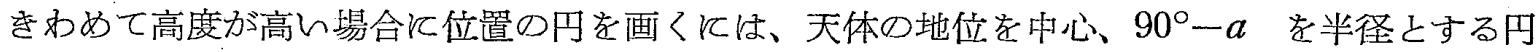
を画けばよん。

平射図法に記入した grid は、その最も極に近ん点の緯度をの゙とすれば、以上の取扱い方と同 様にして、地球面上では反対の極を通る半径 $45^{\circ}-\frac{\varphi_{*}}{2}$ ○小円であるととがわかる。したがつて

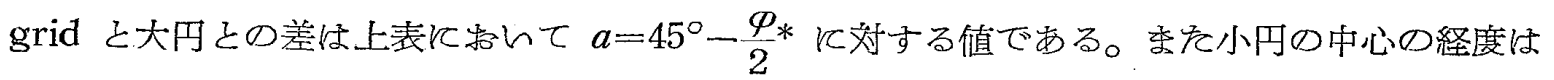


$\pm 90^{\circ}$ 、緯度は $-\left(45^{\circ}-\frac{\varphi_{*}}{2}\right)$ となるから、grid 子午線の方程式は

$$
\pm \sin \lambda=\tan \left(45^{\circ}-\frac{\phi_{*}}{2}\right) \cdot(\sec \varphi+\tan \varphi)
$$

となる。

（付記）この講演後に、極地航法につレて以上と同じ原理に基んた表が Lincoln Ellsworth そよつて編修されているととを知つた。まを仮走位置を極以外飞採つを場合の同様の表は1916 年ドイッで用いられをとのととである。

\section{§8.むすず}

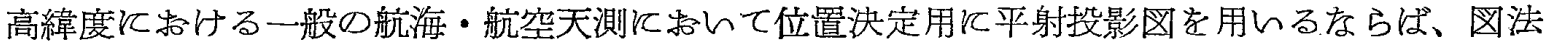

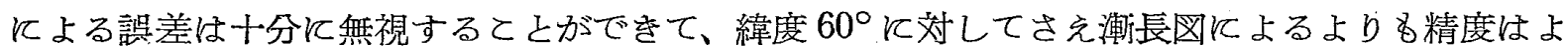
く、さらに高緯度となるにしたがい急激に精度が高くなる。

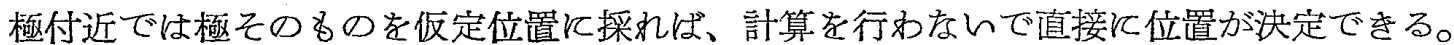

1957 年 2 月 